\title{
Ecological implications of surficial marine gas hydrates for the associated small-sized benthic biota at the Hydrate Ridge (Cascadia Convergent Margin, NE Pacific)
}

\author{
Stefan Sommer*, Olaf Pfannkuche, Dirk Rickert, Anja Kähler
}

GEOMAR, Forschungszentrum für Marine Geowissenschaften, Universität Kiel, Wischhofstraße 1-3, 24148 Kiel, Germany

\begin{abstract}
The effect of methane released from decomposing surficial gas hydrates (SGH) on standing stocks and activities of the small-sized benthic biota (SSBB; i.e. bacteria, fungi, protozoa, and meiobenthic organisms) was studied at about $790 \mathrm{~m}$ water depth, at the Hydrate Ridge, Cascadia subduction zone. Presence of SGH and elevated sulfide concentrations in the sediment were indicated by extensive bacterial mats of Beggiatoa sp. and clam fields of the bivalve mollusc Calyptogena sp. Vertical and horizontal distribution patterns of the SSBB biomass were derived from DNA and total adenylate (TA) sediment assays. Potential bacterial exoenzymatic hydrolytic activity was measured using fluorescein-di-acetate (FDA) as substrate. Estimates of chemoautotrophic production of particulate organic carbon (POC) were determined by ${ }^{14} \mathrm{CO}_{2}$ uptake incubations. Inventories of chl $a$ and pheopigments were determined as parameters of surface water primary produced POC input. Average SSBB biomass in clam field sediments integrated over the upper $10 \mathrm{~cm}\left(765.2 \mathrm{~g} \mathrm{C} \mathrm{m}^{-2}\right.$, SD 190.1) was 3.6 times higher than in the adjacent control sites $\left(213 \mathrm{~g} \mathrm{C} \mathrm{m}^{-2}, \mathrm{SD} 125\right)$. Average SSBB biomass in bacterial mat sediments, which were almost devoid of eukaryotic organisms $>31 \mu \mathrm{m}$, was $209 \mathrm{~g} \mathrm{C} \mathrm{m}^{-2}$ (SD 65). Significant correlations between FDA, DNA and plant pigments imply that productivity of the SSBB at SGH sites is only partially uncoupled from the primary production of the surface water. Areal estimates of autotrophic $\mathrm{C}_{\text {org }}$ production at control sites, bacterial mat sites and in clam field sites were 5.7,59.7 and $190.0 \mathrm{mg} \mathrm{C} \mathrm{m}^{-2} \mathrm{~d}^{-1}$, respectively. Based on different models predicting vertical POC fluxes from surface water primary production and water depth, these autotrophic POC productions account for 5 to $17 \%$ (controls), 35 to $68 \%$ (bacterial mats), and 63 to $87 \%$ (clam fields) of the bulk POC (sum of allochthonous POC input through the water column and sedimentary autochthonous autotrophic POC production) provided at the various sites. At SGH sites inventories of chl $a$ and pheopigments, integrated over the upper $10 \mathrm{~cm}$ of the sediment, were half of that found at the control sites. This might be due to enhanced degradation of phytodetritally associated organic matter. The resulting low molecular weight organic carbon compounds might stimulate and fuel sulfate reduction, which is conducted in a microbial consortium with anaerobic methane consuming archaea. This syntrophic consortium might represent a prominent interface between gas hydrate derived carbon and allochthonous $\mathrm{C}_{\text {org }}$ flow. We infer that degradation kinetics of SGH is affected by, e.g., seasonally varying input of allochthonous organic matter.
\end{abstract}

KEY WORDS: Small-sized benthic biota - Benthic carbon turnover · Gas hydrate · Hydrate Ridge · Cascadia subduction zone

\section{INTRODUCTION}

Marine gas hydrate deposits are well known from accreted sediments at plate collision zones such as the Cascadia margin, as well as from sedimentary regions at passive margins and marginal basins (Kvenvolden 1993). Gas hydrates are solid ice-like structures where low molecular weight compounds, predominantly methane but also ethane, propane and traces of hydrogen sulfide and $\mathrm{CO}_{2}$, are embedded into a lattice of 
water molecules (Sloan 1990, Kvenvolden 1988a, 1993). The global amount of carbon bound in gas hydrates is estimated at $2 \times 10^{3}$ to $4 \times 10^{6}$ gigatons, constituting the earth's largest reservoir of fossil hydrocarbons (Kvenvolden 1988b).

Typically, gas hydrate deposits are present several meters below the sea-floor. The surficial gas hydrate (SGH) deposits at the southern Hydrate Ridge are believed to be formed secondarily. Tectonic uplift and thrusting by convergence between the Juan de Fuca plate and the North American plate cause thrust faults, extensional fractures, and breached folds to develop along the accretionary ridges (Carson \& Westbrook 1995, Kulm et al. 1986, McKay et al. 1992). The faults extend through the accreted sediments to below the gas hydrate phase transition, and serve as conduits along which water and methane from deep hydrate destabilisation is channeled up to the sea-floor, where secondary $\mathrm{H}_{2} \mathrm{~S}-\mathrm{CH}_{4}$ gas hydrates in equilibrium with their surrounding geochemical environment are formed (Kastner et al. 1998, Suess et al. 1999, Tryon et al. 1999).

The SGH at the southern crest of the Hydrate Ridge are presently stable and gas seepage might only be driven by dissociation of the SGH and diffusional transport of the released methane to the sediment surface (Bohrmann et al. 1998). The release of methane from the decomposing $\mathrm{SGH}$ affects the benthic carbon flow to an unknown extent. In SGH sediments, the energy bound in methane is transferred to the higher biota predominantly through bacterial aerobic and anaerobic methane oxidation, presumably via reverse methanogenesis, coupled to the reduction of sulfate (Masuzawa et al. 1992, Hoehler et al. 1994). Only recently, Boetius et al. (2000) provided microscopical evidence of a consortium of methanogenic archaea and sulfate reducing bacteria, which were associated with extremely high sulfate reduction rates in SGH sediments of the southern Hydrate Ridge. This syntrophic consortium releases sulfide into the porewater, which serves as an electron donor for chemosynthetic sulfide oxidising bacteria producing extra $\mathrm{C}_{\text {org }}$ (autochthonous $\mathrm{C}_{\text {org }}$ carbon source) in addition to $\mathrm{C}_{\text {org }}$ settled from the euphotic zone (allochthonous $\mathrm{C}_{\text {org }}$ source). Aerobic methane oxidation using oxygen as a terminal electron acceptor at the sediment surface significantly contributes to the sedimentary carbon turnover at cold seep environments or organically enriched sediments (Dando et al. 1991, 1994, Jensen et al. 1992, Schmaljohann 1996), but aerobic methane oxidation in bacterial mat sediments associated with SGH is of minor importance (Boetius et al. 2000). Its significance in clam field sediments is not known.
In SGH sediments at the southern Hydrate Ridge a specific set of environmental conditions prevails. Autochthonously produced $\mathrm{C}_{\text {org }}$ entering the benthic food web, high sulfide concentrations toxic to aerobic eukaryotes, and low oxygen levels lead to the development of adapted benthic communities, consisting of dense populations of the symbiont bearing vesicomyid clams Calyptogena pacifica and C. kilmeri, solemyid bivalve molluscs of the genus Acharax, and mats of the filamentous sulfide oxidising bacteria Beggiatoa sp. (Suess et al. 1985, 1999, Kulm et al. 1986, Kastner et al. 1995, 1998, Olu et al. 1997, Bohrmann et al. 1998, Boetius et al. 2000, Sahling et al. 2002). Recently, high abundances of a new polychaete species, Hesiocaeca methanicola, have been found in the exposed surface of SGH at a depth of $550 \mathrm{~m}$ in the northern Gulf of Mexico (MacDonald \& Joye 1997, Desbruyères \& Toulmond 1998). Similar benthic communities, including bivalve molluscs, vestimentiferan tubeworms, pogonophorans, gastropods and sponges have been reported from other vent and seep sites not associated with gas hydrates (cf. Olu et al. 1997, Levin et al. 2000).

No information exists on the biomass and activity patterns of the small-sized benthic biota (SSBB) which comprise bacteria, fungi, protozoa and meiofaunal organisms in SGH sediments. This functional group has been studied primarily in deep-sea and continental margin sediments, where the vertical flux of $\mathrm{C}_{\text {org }}$ from primary production at the water surface and lateral $\mathrm{C}_{\text {org }}$ inputs are the predominant food sources for benthic consumers. In these habitats the SSBB responds fast to deposition events of organic matter and to be a major driving force of benthic carbon and nutrient flow.

Olu et al. (1997) found that abundances of non symbiotic detritivorous nematodes at mud volcanoes associated with gas hydrates were 1 to 2 orders of magnitude higher than those recorded from other deep-sea environments at similar water depths. Similarly, enhancement of meiofaunal production stimulated by bacterial chemosynthesis has also been found in cold seep habitats not associated with surficial gas hydrates, both in shallow water environments and in the deep sea (Jensen 1986, Shirayama \& Ohta 1990, 1996, Dando et al. 1991, Jensen et al. 1992, Dando et al. 1994, Zimmermann 1999). At methane seep sites in the Black Sea Luth et al. (1999) detected no elevated biomasses of the SSBB.

The SSBB in sulfidic SGH sediments comprise heterotrophic and autotrophic organisms. Aim of the study is to evaluate the relative contributions of allochthonous and autochthonous POC to the bulk amount of POC available for the benthic food web, and to evaluate the significance of allochthonous organic matter input into a habitat based on chemosynthesis. 


\section{MATERIALS AND METHODS}

Study area and sediment sampling. Samples were collected at 9 stations on the crest of the southern Hydrate Ridge, Cascadia subduction zone, off Oregon, where extensive vent communities, methane hydrate exposures, and authigenic carbonates have been discovered (Bohrmann et al. 2000) (Fig. 1,

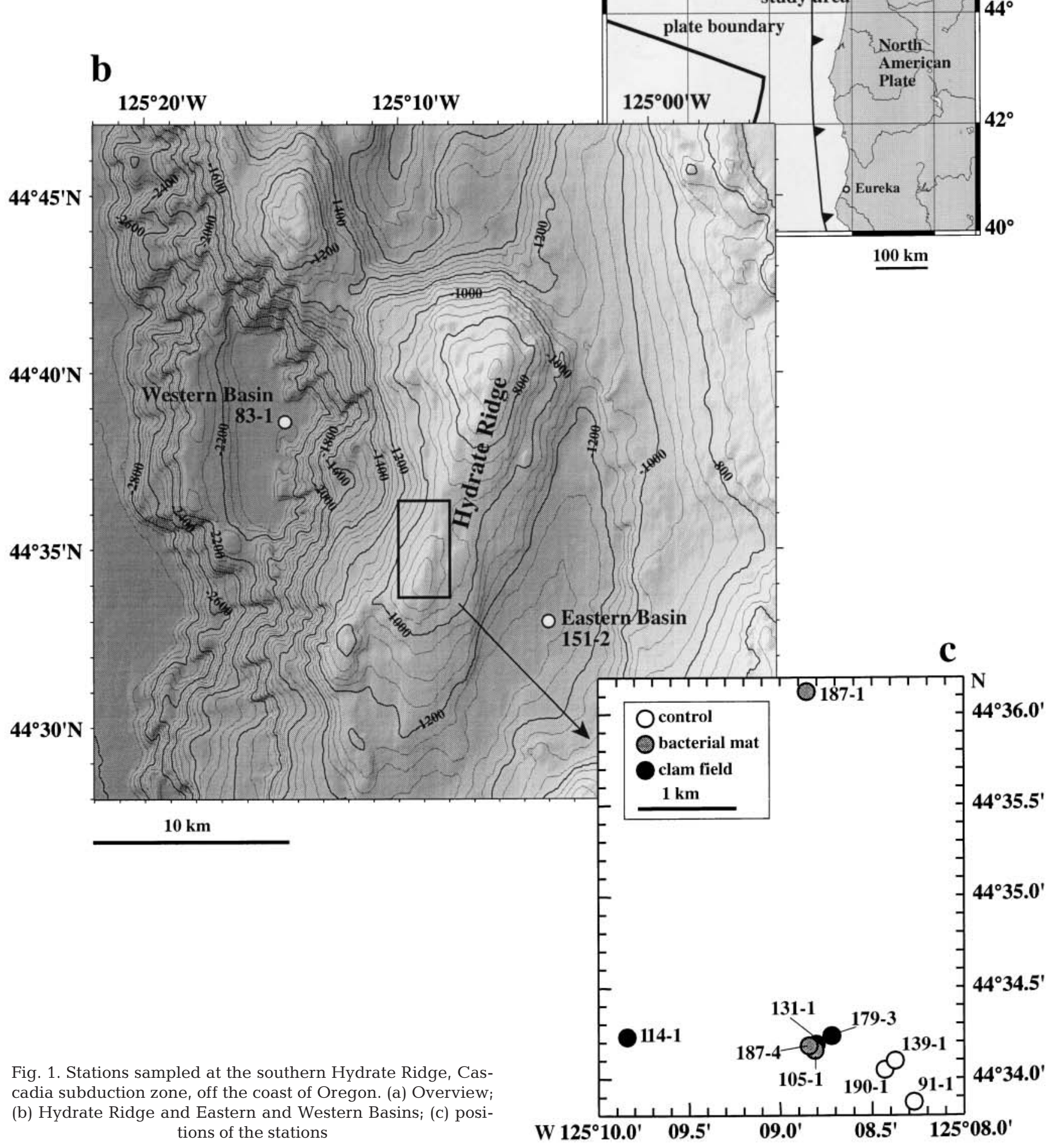


Table 1. Station data of cruise RV 'Sonne' 143/2

\begin{tabular}{|lcccr|}
\hline Site & Habitat & Date & Position & Depth $(\mathrm{m})$ \\
\hline $83-1$ & Western Basin & 02.08 .1999 & $44^{\circ} 38.500^{\prime} \mathrm{N}, 125^{\circ} 14.500^{\prime} \mathrm{W}$ & 2304 \\
$151-2$ & Eastern Basin & 14.08 .1999 & $44^{\circ} 33.000^{\prime} \mathrm{N}, 125^{\circ} 04.000^{\prime} \mathrm{W}$ & 1285 \\
$91-1$ & Control & 04.08 .1999 & $44^{\circ} 33.880^{\prime} \mathrm{N}, 125^{\circ} 08.290^{\prime} \mathrm{W}$ & 852 \\
$139-1$ & $"$ & 12.08 .1999 & $44^{\circ} 34.100^{\prime} \mathrm{N}, 125^{\circ} 08.380^{\prime} \mathrm{W}$ & 826 \\
$190-1$ & $"$ & 20.08 .1999 & $44^{\circ} 34.050^{\prime} \mathrm{N}, 125^{\circ} 08.410^{\prime} \mathrm{W}$ & 824 \\
$105-1$ & With microbial mat & 06.08 .1999 & $44^{\circ} 34.140^{\prime} \mathrm{N}, 125^{\circ} 08.810^{\prime} \mathrm{W}$ & 787 \\
$187-1$ & " & 19.08 .1999 & $44^{\circ} 36.160^{\prime} \mathrm{N}, 125^{\circ} 08.860^{\prime} \mathrm{W}$ & 786 \\
$187-4$ & $"$ & 19.08 .1999 & $44^{\circ} 34.190^{\prime} \mathrm{N}, 125^{\circ} 08.820^{\prime} \mathrm{W}$ & 785 \\
$114-1$ & With clams & 07.08 .1999 & $44^{\circ} 34.210^{\prime} \mathrm{N}, 125^{\circ} 09.850^{\prime} \mathrm{W}$ & 786 \\
$131-1$ & $"$ & 10.08 .1999 & $44^{\circ} 34.180^{\prime} \mathrm{N}, 125^{\circ} 08.800^{\prime} \mathrm{W}$ & 785 \\
$179-3$ & " & 17.08 .1999 & $44^{\circ} 34.210^{\prime} \mathrm{N}, 125^{\circ} 08.740^{\prime} \mathrm{W}$ & 786 \\
\hline
\end{tabular}

Table 1). SGH sites can be separated into 3 habitats characterised by dominant organisms along a gradient of sulfide diffusion (Sahling et al. 2002). Mats of Beggiatoa sp. occur directly above SGH (Sites 105-1, 187-1 and 4 ; Fig. 1c) in association with high sulfide fluxes in zones where the sulfide front reaches the surface of the sediment; these bacterial mats were sampled along with the underlying sediment. At reduced sulfide fluxes and a lowering of the sulfide front several centimetres into the sediment, the outer rim of the bacterial mats is densely populated by vesicomyid clams of the genus Calyptogena (Sites 114-1, 131-1, 179-3; Fig. 1c). Sediments with low sulfide fluxes are characterised by the burrowing solemyid bivalve mollusc Acharax sp.

Control samples (Sites 91-1, 139-1, 190-1; Fig. 1c) were obtained from locations without SGH, a few hundreds of meters from the SGH sites at the SE slope of Hydrate Ridge. These sediments had no dissolved sulfide (Rickert unpubl. data). More distant reference samples were taken 10 to $15 \mathrm{~km}$ from the SGH sites at the Eastern (Site 151-2) and Western Basin (Site 83-1) flanking Hydrate Ridge. All samples were obtained during cruise 143/2 with RV 'Sonne' in August 1999 (Bohrmann et al. 2000).

A multiple corer (MUC) based on the design of Barnett et al. (1984) was used to collect almost undisturbed samples of surface sediments. The MUC was equipped with an online video TV system to allow controlled sampling of the sea floor. The MUC retrieved up to 8 sediment cores of $10 \mathrm{~cm}$ diameter and $35 \mathrm{~cm}$ maximum length. Upon recovery, the cores were immediately transferred to a $4^{\circ} \mathrm{C}$ room for further processing.

The MUC cores were subsampled with cut-off syringes of $1.1 \mathrm{~cm}$ diameter for the determination of plant pigments and ${ }^{14} \mathrm{CO}_{2}$ uptake incubations, and of $2.1 \mathrm{~cm}$ diameter for all other parameters. Subsamples were sectioned horizontally in $1 \mathrm{~cm}$ intervals down to a depth of $10 \mathrm{~cm}$, and in $3 \mathrm{~cm}$ intervals down to a depth of $28 \mathrm{~cm}$ where possible. From each core, at least
3 subsamples (cut-off syringes) were taken for all parameters (except for ${ }^{14} \mathrm{CO}_{2}$ uptake incubations: 2 replicates from each core), unless otherwise indicated.

Biochemical analyses. DNA measurements were used as an estimate of SSBB biomass. DNA concentrations were determined fluorometrically with DAPI based on the method given by Kapuscinski \& Skoczylast (1977), modified for natural sediments by Teucher (1986). This method is specific for double-stranded DNA reflecting the presence of living cells.

As a further proxy of the biomass of the SSBB, total adenylates (TA), which represent the sum of the concentrations of ATP, ADP, and AMP, were analysed. TA mainly reflect the amount of plasma within the cells and are therefore closely related to biovolume (Karl 1993). Concentrations of TA were measured using 'firefly' following the method by Pfannkuche et al. (1999).

Potential activity of hydrolytic enzymes was measured fluorimetrically with fluorescein-di-acetate (FDA) as substrate with a modified method after Meyer-Reil \& Köster (1992) as specified by Pfannkuche et al. (1999).

Chl a and pheopigment concentrations were measured as parameters indicating the input of phytoplankton $\mathrm{C}_{\text {org }}$. Their concentrations were determined using a Turner fluorometer according to Yentsch \& Menzel (1963) and Holm-Hansen et al. (1965), as described by Pfannkuche et al. (1999).

To resolve the non-photosynthetic endogenous production of POC in the sediment, chemoheterotrophic and chemoautotrophic ${ }^{14} \mathrm{CO}_{2}$ uptake into sediment particulate organic matter was analysed according to the method given by Hollinde (1995) and modified by Schmaljohann et al. (2001). ${ }^{14} \mathrm{CO}_{2}$ uptake was measured after 3 injections of $9 \mu \mathrm{H} \mathrm{H}^{14} \mathrm{CO}_{3}{ }^{-}$into each subsample (cut-off syringes: $5 \mathrm{~cm}$ long, $1.1 \mathrm{~cm}$ in diameter), corresponding to an activity of $475200 \mathrm{dpm}$ per $1 \mathrm{~cm}$ depth interval. These cores were incubated in the dark at in situ temperatures of about $4^{\circ} \mathrm{C}$ for $24 \mathrm{~h}$. Subsequently the sediment was sectioned horizontally in $1 \mathrm{~cm}$ depth intervals. To halt bacterial activity after incubation, each $1 \mathrm{~cm}$ layer of the sediment was suspended in a centrifuge tube containing $5 \mathrm{ml} 0.3 \mathrm{~N} \mathrm{HCl}$. Excess $\mathrm{H}^{14} \mathrm{CO}_{3}{ }^{-}$not used for $\mathrm{CO}_{2}$ fixation escaped as ${ }^{14} \mathrm{CO}_{2}$ into the atmosphere. After leaving the centrifuge tubes open for $15 \mathrm{~min}$, they were centrifuged and the liquid phase was decanted. The acidification procedure was repeated twice. Subsequently, the sediment pellet was dried at $60^{\circ} \mathrm{C}$ for $48 \mathrm{~h}$, ground with a mortar and pestle and weighed (200 to $400 \mathrm{mg}$ ) into Packard Combusto Cones, which were pressed to pel- 
lets. These were combusted in a Biological Oxidiser, OX 500 (Zinser Analytic), and the escaping ${ }^{14} \mathrm{CO}_{2}$ was sampled in scintillation vials containing a mixture of Packard Carbo Sorb E and Packard Permaflour V at a ratio of $3 / 7$ (vol./vol.). Sampling efficiency of the oxidiser was calibrated using a Packard Spec Check ${ }^{14} \mathrm{C}$ (activity: $9.24 \times 10^{5} \pm 3 \% \mathrm{dpm} \mathrm{ml} \mathrm{m}^{-1}$ ). ${ }^{14} \mathrm{C}$ activity was determined by scintillation counting (Packard scintillation counter, Tri Carb 2100TR). Data of dissolved inorganic carbon concentrations (DIC) for the calculation of ${ }^{14} \mathrm{CO}_{2}$ uptake into the sediment particulate organic carbon (POC) were provided by D. Rickert (unpubl.).

Statistical analyses. Pearson correlation analyses were employed for the correlation between the biogeochemical parameters chl $a$, pheopigments, FDA, ${ }^{14} \mathrm{CO}_{2}$ uptake, DNA and TA. Analyses of covariance were used to test differences between biogeochemical parameters using the same covariate. All tests were conducted with the Statistica software package Version 3.0a.

\section{RESULTS}

\section{Sediment pigment concentrations}

Sediment chl a and pheopigment inventories integrated over the upper $10 \mathrm{~cm}$ of the sediment, representing the active zone, are shown in Fig. 2a,b. At SGH sites the average overall sediment concentrations of chl $a$ and pheopigments were about 0.5 times lower than at the control sites. In clam field sediments pigment concentrations were slightly higher than in bacterial mat sediments.

Typical vertical concentration profiles of chl $a$ and pheopigments for the more distant reference station in the Eastern Basin at the flank of the Hydrate Ridge (Site 151-2), a control site (Site 190-1) adjacent to the SGH sites, bacterial mats (Sites 187-1 and 187-4) and clam field sediments (Site 179-3) are shown in Fig. 3. In bacterial mat sediments, the vertical distributions of chl $a$ and pheopigments show distinct surface peaks followed by an exponential decrease. This indicates that there is almost no bioturbation, and degradation of chl $a$ is faster than its influx. In clam field sediments chl $a$ is distributed deeper into the sediment, and below a depth of about $5 \mathrm{~cm}$ chl a concentration decreases steadily. The respective pheopigment concentration declines gradually with depth. The chl a profile at the control site displays a distinct subsurface maximum at a depth of $2 \mathrm{~cm}$, below which chl a concentrations decrease gradually. This subsurface maximum is not present in the distribution of pheopigment concentrations which decrease continuously with depth. In the Eastern Basin, vertical chl $a$ and pheopigment distributions showed a surface minimum, with increasing depth pigment concentrations remained relatively constant.

\section{Bacterial exoenzymatic activity (FDA turnover)}

The turnover of fluorescein-di-acetate (FDA) indicates the potential activity of extracellular hydrolytic enzymes, representing a first step in the bacterial degradation of organic matter. Highest FDA turnover rates, integrated over the upper $10 \mathrm{~cm}$ of the sediment,
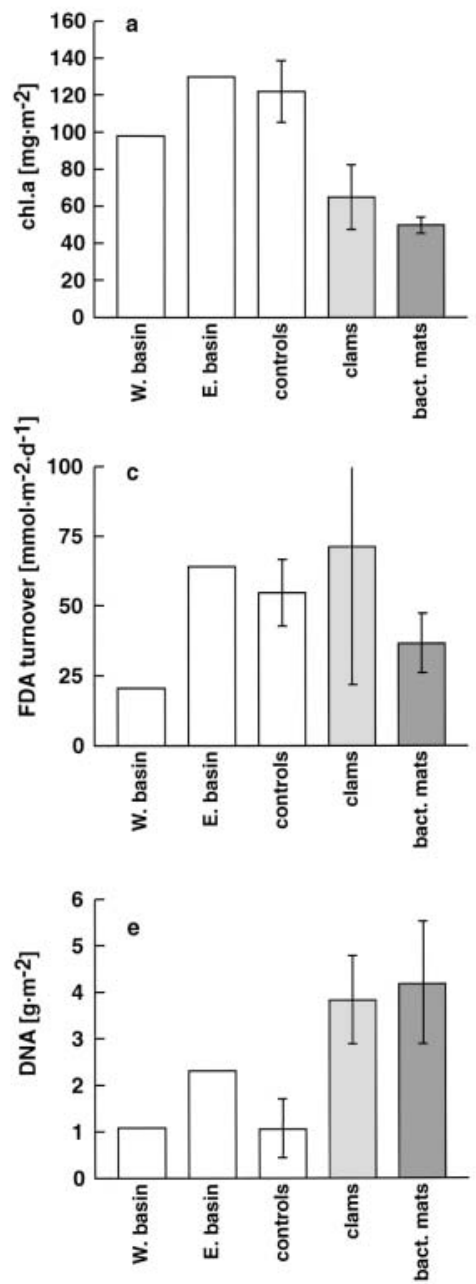

Fig. 2. Inventories ( $\pm \mathrm{SD}$ ) of (a) chl a concentrations; (b) pheopigment concentrations; (c) FDA turnover; (d) ${ }^{14} \mathrm{CO}_{2}$ uptake rates; (e) DNA concentrations; (f) TA, in the upper $10 \mathrm{~cm}$ of the sediment. * = outlier of $7 \mathrm{mmol} \mathrm{m}^{-2}$ at Stn 187-1/4 (average TA inventory at bacterial mat sediments was not calculated). Stations with a grey shading are SGH sites 


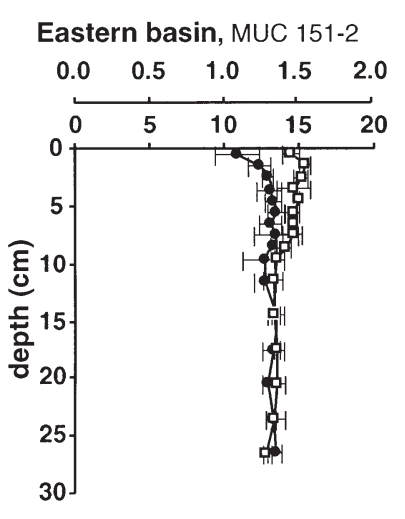

Control site, MUC 190-1
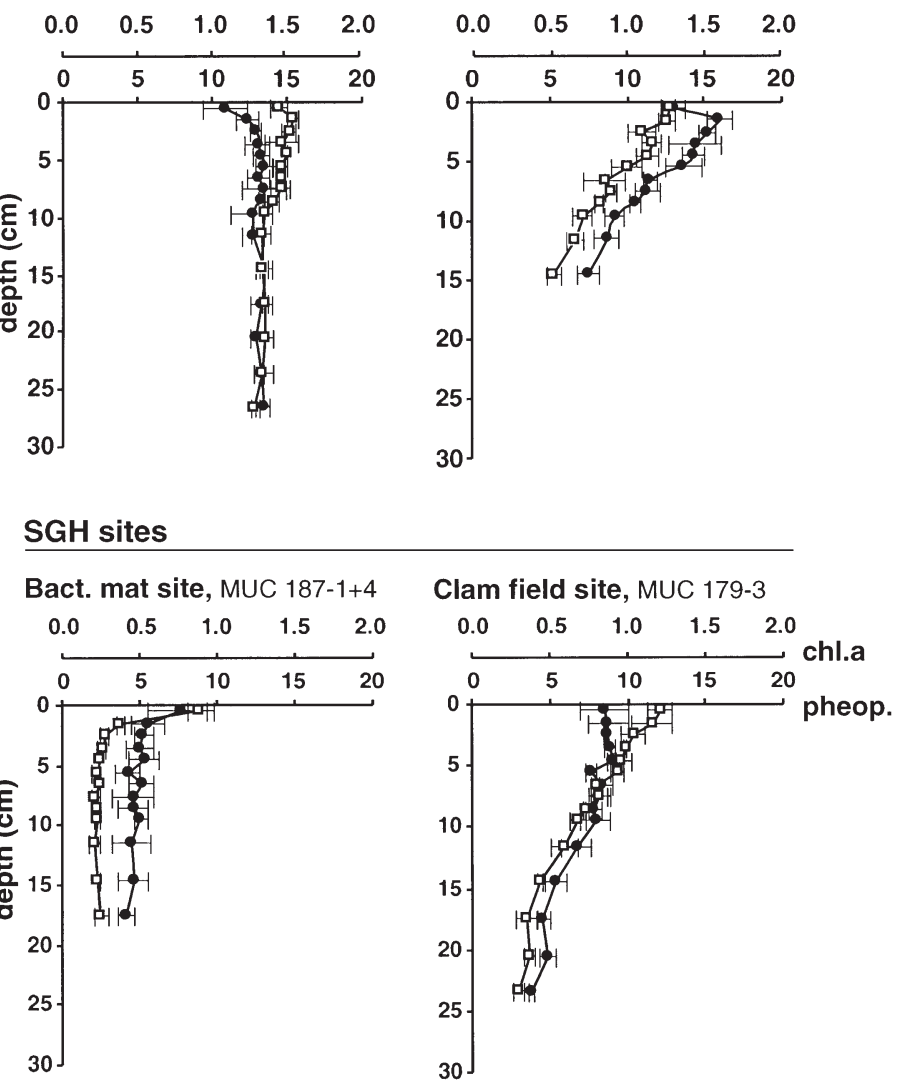

Fig. 3. Vertical profiles of concentrations $\left( \pm \mathrm{SD}_{i} \mathrm{n}=3\right.$ ) of chl $a$ (•) and pheopigment () at Eastern Basin, control and SGH sites

of up to $114.5 \mathrm{mmol} \mathrm{m} \mathrm{m}^{-2} \mathrm{~d}^{-1}$ were measured in clam field sediments (Site 179-3, Fig. 2c). FDA turnover in bacterial mat sediment was lower than those found at the control sites. FDA turnover measured in the Eastern Basin was $64.1 \mathrm{mmol} \mathrm{m}^{-2} \mathrm{~d}^{-1}$, whereas FDA turnover in sediments of the Western Basin was relatively low $\left(20.6 \mathrm{mmol} \mathrm{m}^{-2} \mathrm{~d}^{-1}\right)$.

Typical vertical distributions of exoenzymatic hydrolytic activity at the different sites are shown in Fig. 4. In sediments covered by bacterial mats, the highest activity was found in the uppermost 3 to $5 \mathrm{~cm}$, and below this depth FDA turnover decreased rapidly. In clam field sediments, elevated FDA turnover rates were also measured in deeper sediment horizons. At the control site, FDA turnover rates showed a distinct subsurface peak. In the Eastern Basin, FDA turnover was lowest at the sediment surface, increased slightly with depth and remained constant below a depth of about $4 \mathrm{~cm}$. Generally, depth distributions of FDA coincided with the distributions of chl $a$, which was particularly evident at the control sites (subsurface maxima) and more distant reference sites.

\section{${ }^{14} \mathrm{CO}_{2}$ uptake into the particulate organic matter of the sediment}

${ }^{14} \mathrm{CO}_{2}$ uptake rates integrated over the upper $10 \mathrm{~cm}$ of the sediment in bacterial mat sediments were 10.5 times higher than at the control sites (Fig. 2d). The average ${ }^{14} \mathrm{CO}_{2}$ uptake rate in clam field sediments was 3.2 times higher than that determined at the bacterial mat sites and 33.3 times that of the control sites with a maximum ${ }^{14} \mathrm{CO}_{2}$ uptake rate of $324 \mathrm{mg} \mathrm{C} \mathrm{m}^{-2} \mathrm{~d}^{-1}$. The ${ }^{14} \mathrm{CO}_{2}$ uptake rates at the Western and Eastern Basins were 2.5 -fold higher than those measured at the control sites.

Fig. 5 shows typical vertical distributions of the ${ }^{14} \mathrm{CO}_{2}$ uptake rates at the different sites. At the control site there is a distinct surface maximum of the specific ${ }^{14} \mathrm{CO}_{2}$ uptake rates with a second subsurface maximum at depth of $3 \mathrm{~cm}$. In bacterial mat sediments, specific ${ }^{14} \mathrm{CO}_{2}$ uptake rates were highest at the surface of the sediment associated with very steep depth gradients, whereas in clam field sediments ${ }^{14} \mathrm{CO}_{2}$ uptake rates were low in the uppermost centimetres of the sedi-

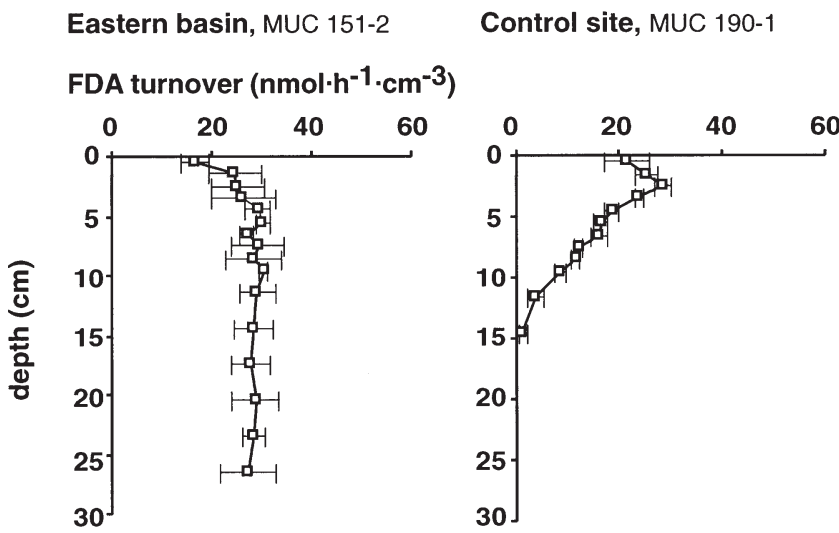

\section{SGH sites}

Bact. mat site, MUC 187-1+4

Clam field site, MUC 179-3
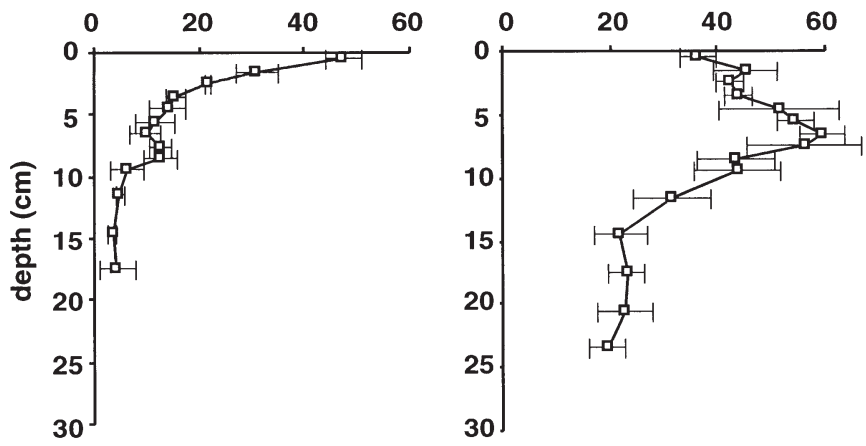

Fig. 4. Vertical profiles of FDA turnover rates $\left( \pm \mathrm{SD}_{i} \mathrm{n}=3\right)$ at Eastern Basin, control and SGH sites 


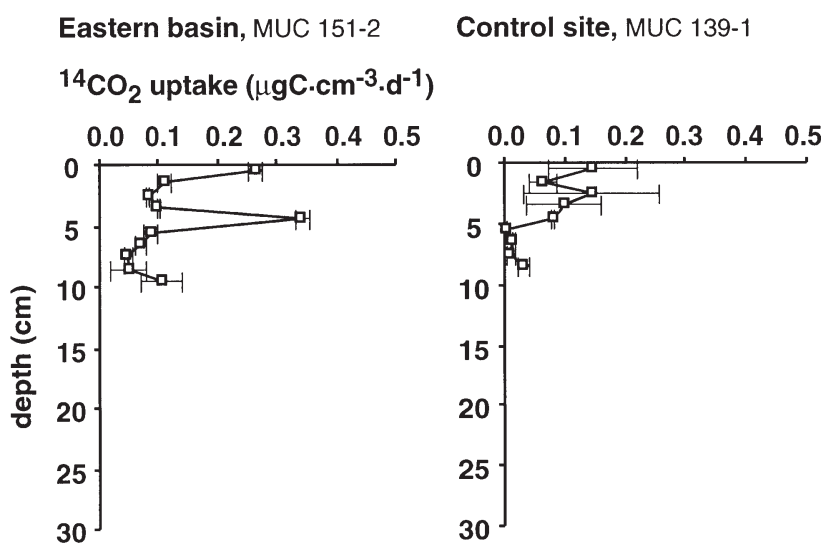

SGH sites

Bact. mat site, MUC 105-1

Clam field site, MUC 179-3
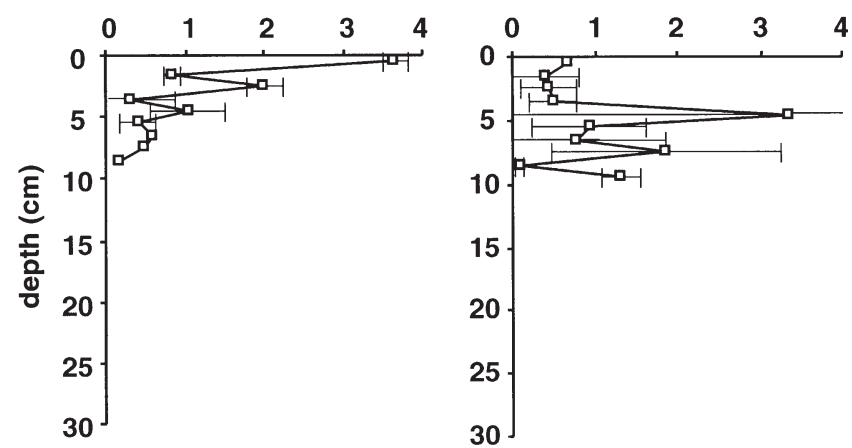

Fig. 5. Vertical profiles of ${ }^{14} \mathrm{CO}_{2}$ uptake rates $( \pm \mathrm{SD} ; \mathrm{n}=2)$ into the particulate matter of the sediment at Eastern Basin, control and SGH sites

ment, but strongly increased with depth. The Eastern Basin sediments showed surface- and subsurface maxima of ${ }^{14} \mathrm{CO}_{2}$ uptake rates at a depth of about $5 \mathrm{~cm}$.

\section{DNA}

DNA inventories integrated over the upper $10 \mathrm{~cm}$ of the sediment were 3.5 and 3.9 times higher in clam field and bacterial mat sediments, respectively, than those found at the control sites (Fig. 2e). The average DNA inventory at bacterial mats $\left(4.2 \mathrm{~g} \mathrm{~m}^{-2}\right.$, range: 3.2 to 5.1$)$ is similar to that found in clam field sediments $\left(3.8 \mathrm{~g} \mathrm{~m}^{-2}\right.$, range: 3.1 to 4.9$)$. DNA stocks at the Western Basin are similar to those of the control sites. At the Eastern Basin, DNA stocks are twice as high as at the control sites and the Western Basin.

The highest DNA concentrations, representing 28.1 to $34.6 \%$ of the total DNA inventory, were found at bacterial mat sites in the top $2 \mathrm{~cm}$ of the sediment
(Fig. 6). These high DNA concentrations coincided with the occurrence of Beggiatoa spp., and decreased rapidly with depth. In clam field sediments, the vertical distribution of DNA concentration was variable and decreased only very little with depth. At the control site and the Eastern Basin, DNA concentrations were highest at the surface of the sediment and declined steadily with depth.

\section{Total adenylates (TA)}

TA was determined as a measure of the biomass of the SSBB and mainly reflects the amount of plasma within the cells. Average inventories of TA integrated over the upper $10 \mathrm{~cm}$ of the sediment at the clam field and bacterial mat sites exceed those of the control sites by factors of 3.5 and 5.9, respectively (Fig. 2f). The TA inventory analysed at Stn 187-1/4 was excluded, because it was extraordinarily high $\left(7.0 \mathrm{mmol} \mathrm{m}^{-2}\right)$ and might represent an outlier. In the Western and Eastern Basins we found relatively high inventories of TA ( 54.2 and $64.7 \mu \mathrm{mol} \mathrm{m}^{-2}$, respectively).

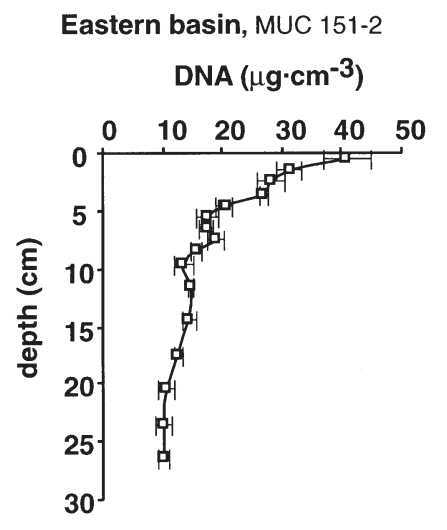

Control site, MUC 190-1

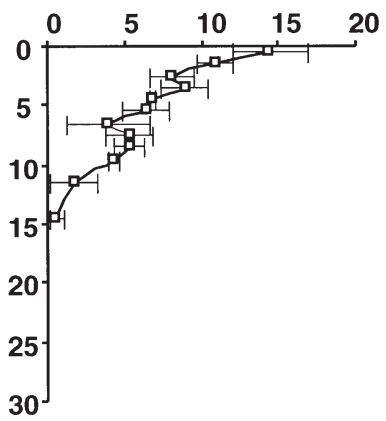

SGH sites

Bact. mat site, MUC 187-1+4

Clam field site, MUC 179-3

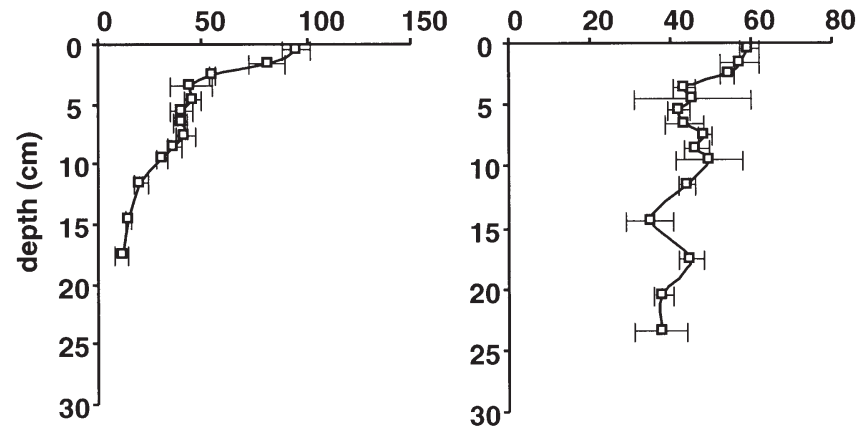

Fig. 6. Vertical profiles of DNA concentrations $\left( \pm \mathrm{SD}_{i} \mathrm{n}=3\right)$ at Eastern Basin, control and SGH sites 
Differences in the shape of the vertical distribution of TA were detected between bacterial mat and clam field sediments (Fig. 7). In bacterial mat sediments, TA was highest in the upper $8 \mathrm{~cm}$ of the sediment, and rapidly decreased with increasing depth. In clam field sediments, TA concentrations were low in surficial sediment layers and increased continuously with depth reaching maximum concentrations around $20 \mathrm{~cm}$ sediment depth. Vertical distributions of TA at the control sites and the basins showed distinct surface maxima, and below a sediment depth of 3 to $5 \mathrm{~cm}$, TA concentrations decreased sharply.

\section{Correlation between SSBB standing stocks, FDA turnover, ${ }^{14} \mathrm{CO}_{2}$ uptake rates and phytopigments}

Pearson correlation analyses between DNA, TA, plant pigments concentrations, FDA turnover and ${ }^{14} \mathrm{CO}_{2}$ uptake rates from all $1 \mathrm{~cm}$ depth horizons of the upper $10 \mathrm{~cm}$ of the sediment were conducted separately for control sites and SGH sites (Table 2). Data

\section{Eastern basin, MUC 151-2 Control site, MUC 190-1}

\section{total adenylates (pmol.cm-3)}

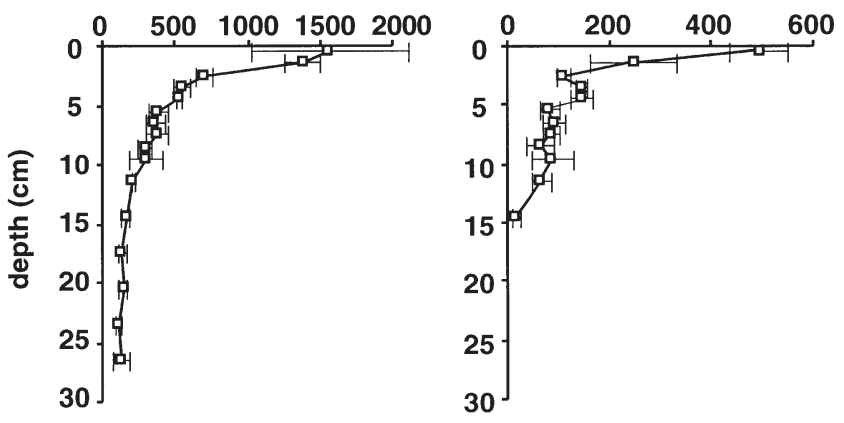

\section{SGH sites}

Bact. mat site, MUC 187-1+4

Clam field site, MUC 179-3

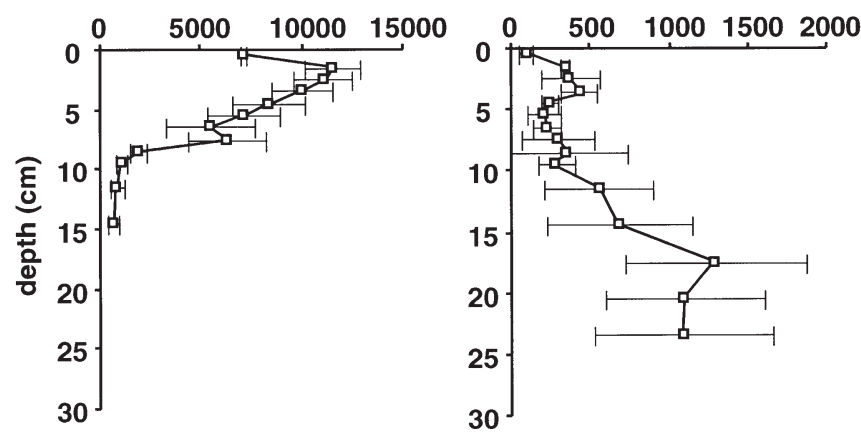

Fig. 7. Vertical profiles of TA (total adenylate) concentrations $( \pm \mathrm{SD} ; \mathrm{n}=3)$ at Eastern Basin, control and SGH sites
Table 2. Correlation matrix between depth-specific FDA turnover rates, concentrations of TA (total adenylates), DNA, chl $a_{1}$ pheopigments (pheo), and ${ }^{14} \mathrm{CO}_{2}$ uptake rates. Upright figures are for control sites, those in italics are for SGH sites; ns: not significant $(p>0.01)$

\begin{tabular}{|c|c|c|c|c|c|c|}
\hline & FDA & TA & DNA & $\operatorname{chl} a$ & pheo & ${ }^{14} \mathrm{CO}_{2}$ \\
\hline FDA & & $\begin{array}{c}0.52 \\
n s\end{array}$ & $\begin{array}{l}0.80 \\
0.64\end{array}$ & $\begin{array}{l}0.84 \\
0.74\end{array}$ & $\begin{array}{l}0.86 \\
0.81\end{array}$ & $\begin{array}{l}\mathrm{ns} \\
n s\end{array}$ \\
\hline TA & & & $\begin{array}{l}0.51 \\
0.48\end{array}$ & $\begin{array}{c}0.41 \\
n s\end{array}$ & $\begin{array}{c}0.68 \\
n s\end{array}$ & $\begin{array}{c}0.44 \\
n s\end{array}$ \\
\hline DNA & & & & $\begin{array}{l}0.69 \\
0.48\end{array}$ & $\begin{array}{l}0.83 \\
0.55\end{array}$ & $\begin{array}{l}\mathrm{ns} \\
n s\end{array}$ \\
\hline $\operatorname{chl} a$ & & & & & $\begin{array}{l}0.90 \\
0.87\end{array}$ & $\begin{array}{l}\text { ns } \\
n s\end{array}$ \\
\hline pheo & & & & & & $\begin{array}{c}0.58 \\
n s\end{array}$ \\
\hline
\end{tabular}

from the Western and Eastern Basin were not included in these analyses.

At the control sites DNA was correlated to pheopigments, FDA and chl a. Weak correlations existed between TA, and pheopigments, FDA and chl $a$.

At SGH sites the correlations between DNA, TA, FDA turnover and plant pigments were generally weaker than at the control sites (Table 2). Only about $50 \%$ of the variation in DNA concentrations at the different sediment horizons at SGH sites was explained by the concentrations of pheopigments and chl $a$. Correlations of TA with plant pigments were not significant. It appears that there is a negative trend between TA, pheopigments and chl a. FDA was strongly correlated with pheopigments, chl $a$ and DNA.

At control and SGH sites correlations between ${ }^{14} \mathrm{CO}_{2}$ uptake rates and any other parameter were not significant, except weak correlations with pheopigments at the control sites $(r=0.56)$ and TA $(r=0.26)$.

\section{DISCUSSION}

\section{Standing stocks of SSBB and allochthonous vs autochthonous organic carbon supply}

SGH sites displayed higher DNA and TA concentrations in comparison to the adjacent control sites and the deeper reference sites in the Eastern and Western Basins. No differences in the inventories of DNA and TA were found between bacterial mat and clam field sediments. Whereas low within site variability of DNA and TA inventories occurred at the control sites, at the SGH sites these inventories displayed great variability, which indicates pronounced differences in SSBB composition and standing stock. Gutzmann (2002) found distinct shifts in the community composition of meio- 
faunal assemblages between the control, clam field and bacterial mat sediments sampled during the same cruise. At SGH sites, difficulties in sediment sampling and slicing caused by carbonate crusts, shell debris and large bivalve molluscs may have introduced additional variability.

DNA and TA are bulk parameters for SSBB biomass. The different proportions of bacteria, protozoa, and metazoan meiobenthic organisms cannot be separated with these analyses. The DNA:carbon ratio varies between 1:50 in bacteria and up to 1:500 in eucaryotes (Pfannkuche et al. 2000). Thus, conversion of DNA measurements into $\mathrm{C}_{\text {org }}$ equivalents only allows crude estimates of the total amount of $\mathrm{C}_{\text {org }}$ bound in the SSBB (Table 3). We assumed a conversion factor of 200 for the control sites and for the clam field sediments, which should account for a mixed population of bacteria, protozoans and metazoan meiobenthic organisms (Pfannkuche et al. 2000). The average SSBB biomass at the clam fields integrated over the upper $10 \mathrm{~cm}$ of the sediment was calculated to be $765.2 \mathrm{gC} \mathrm{m}^{-2}$ ( $\mathrm{n}=3$; range: 615 to 980 ), which is 3.6 times higher than the standing stocks at the control sites $\left(213 \mathrm{gC} \mathrm{m}^{-2}, \mathrm{n}=3\right.$; range: 132 to 357). Meiofaunal biomass (organisms $>30 \mu \mathrm{m})$ in bacterial mat sediments $\left(0.594 \mathrm{~g} \mathrm{C} \mathrm{m}^{-2}\right)$ was 3.4 to 3.6 times lower than in the clam field and control sediments (Gutzmann 2002), indicating the predominance of bacteria in this habitat. Thus, a conversion factor of 50 was used to calculate an average bacterial biomass of $209 \mathrm{gC} \mathrm{m}^{-2}$ ( $\mathrm{n}=2$; range: 161.9 to $255.1 \mathrm{gC}$ $\mathrm{m}^{-2}$ ) for bacterial mat sites. In comparison to the biomass determined at the control sites, this estimate is relatively low. The genus Beggiatoa consists of filamentous, often vacuolate bacteria characterised by large

Table 3. Contribution of allochthonous POC (from primary production in surface waters) compared to autochthonous POC (produced autotrophically within the sediment; $\left({ }^{14} \mathrm{CO}_{2}\right.$ uptake) to the bulk POC pool available to the benthic food web at control and SGH sites. Vertical allochthonous organic carbon fluxes calculated from data on water depth and surface water primary production by empirical equations (Suess 1980, Betzer et al. 1984, Berger et al 1987, Pace et al. 1987). DNA-derived biomasses of the small-sized benthic biota (SSBB) were calculated using a conversion factor of 50 for bacterial mats and 200 for control sites and clam field sediments

\begin{tabular}{|lccc|}
\hline & Control sites & \multicolumn{2}{c|}{ SGH sites } \\
& & Microbial mats & Clam fields \\
\hline $\begin{array}{l}\text { SSBB biomass }\left(\mathrm{g} \mathrm{Cm}^{-2}\right) \\
\text { Bulk } \mathrm{C}_{\text {org }}\left(\mathrm{mg} \mathrm{C} \mathrm{m}^{-2} \mathrm{~d}^{-1}\right)\end{array}$ & 213.0 & 209.0 & 765.2 \\
$\begin{array}{c}\text { Allochthonous Corg input } \\
\left(\mathrm{mg} \mathrm{C} \mathrm{m}^{-2} \mathrm{~d}^{-1}\right)\end{array}$ & $27.1-111.9$ & $88.0-170.0$ & $218.3-300.3$ \\
$\begin{array}{c}\text { Autochthonous } \mathrm{C}_{\text {org }} \text { input } \\
\left(\mathrm{mg} \mathrm{C} \mathrm{m}^{-2} \mathrm{~d}^{-1}\right)\end{array}$ & 5.7 & $28.3-110.3$ & $28.3-110.3$ \\
$\begin{array}{c}\text { Autochthonous } \mathrm{C}_{\text {org }} \text { as } \\
\text { proportion of bulk } \mathrm{C}_{\text {org }}(\%)\end{array}$ & $\mathbf{5 . 1 - 1 7 . 4}$ & $\mathbf{3 5 . 1 - 6 7 . 8}$ & $\mathbf{6 3 . 2 - 8 7 . 0}$ \\
\hline
\end{tabular}

cell volumes. The cytoplasm is a thin film attached to the cell walls. Thus, the above conversion factor underestimates the bacterial biomass and should be considered a minimum value.

Apart from representing an important electron donor for chemoautotrophic processes, sulfide is toxic to aerobic metazoans, because it blocks the cytochrome $c$ oxidase of their respiratory chain (Baggarinao 1992). Some infaunal metazoans have developed sulfide detoxification mechanisms to cope with medium-term (Vismann 1991), but they avoid habitats characterised by permanently elevated sulfide levs. This and the lack of oxygen explain the extremely abundances of metazoans in bacterial mat sedicomparison to clam field sediments. Assuming that the $1 \mathrm{~cm}$ surface Beggiatoa sp., its biomass would be $35.5 \mathrm{gC} \mathrm{m}^{-2}$. In Danish fjord sediments, Beggiatoa sp. attain up to $20 \mathrm{~g}$ fresh biomass $\mathrm{m}^{-2}$ (Jørgensen 1987). The biomass of Thioploca sp., a close relative of Beggiatoa sp., at the Chilean shelf was reported to be up to $1000 \mathrm{~g}$ wet w $\mathrm{m}^{-2}$ (Gallardo 1977), corresponding to $100 \mathrm{~g}$ wet wt $\mathrm{m}^{-2}$ contribution to the sedimentary POC was assessed by measuring the ${ }^{14} \mathrm{CO}_{2}$ uptake into the particulate organic matter of the sediment. Apart from autotrophic processes, this method also detects $\mathrm{CO}_{2}$ 'fixation' processes such as acetogenesis and methanogenesis. In Chilean shelf sediments dominated by Thioploca mats, acetogenesis is a pathway between fermentation and sulfate reduction, contributing about $1 \%$ to the total ${ }^{14} \mathrm{CO}_{2}$ uptake (Ferdelman et al. 1997). In SGH sediments, a 24 -fold increase in autochthonous production of organic carbon was measured in comparison to $5.7 \mathrm{mgC} \mathrm{m}^{-2}$ $\mathrm{d}^{-1}$ at the control sites. In shallow water muddy sediments incubated in the dark (Hollinde 1995), and in sediments dominated by Thioploca spp. (Ferdelman et al. 1997) areal estimates of ${ }^{14} \mathrm{CO}_{2}$ uptake were in the range of 67.2 to $132 \mathrm{mgC} \mathrm{m}^{-2} \mathrm{~d}^{-1}$. In the 600 to $800 \mathrm{~m}$ deep Makran area (Arabian Sea) Schmaljohann et al. (2001) found 
depth-specific ${ }^{14} \mathrm{CO}_{2}$ uptake rates of 0.06 to $0.14 \mu \mathrm{gC}$ $\mathrm{cm}^{-3} \mathrm{~d}^{-1}$, which are in the same range as those found at the control sites during this study.

In bacterial mat sediments, diffusive sulfide flux rates range between 21.9 and $27.4 \mathrm{mmol} \mathrm{m}^{-2} \mathrm{~d}^{-1}$ (D. Rickert pers. obs., Sahling et al. 2002). To provide estimates of the carbon production by Beggiatoa based on the sulfide flux we assumed molar growth yields for sulfide of 8.3 and 15.9 (g dry wt $\mathrm{mol}^{-1}$ sulfide), as reported for marine strains of facultative and obligate autotrophic Beggiatoa (Hagen \& Nelson 1997); however, these molar growth yields were determined under optimal growth conditions in static cultures which might be very different from in situ conditions. The above sulfide fluxes yield 91 to $218 \mathrm{mg} \mathrm{C} \mathrm{m}^{-2} \mathrm{~d}^{-1}$ if sulfide is completely oxidised. These values are in the range of the ${ }^{14} \mathrm{CO}_{2}$ uptake rates found in the bacterial mat sediments (Table 3), indicating that chemoautotrophic growth of Beggiatoa sp. is the major pathway providing autochthonous POC to the sediment. Applying an oxygen consumption rate of $1 \mathrm{~mol} \mathrm{O}_{2}$ per $0.58 \mathrm{~mol}$ of sulfide (Hagen \& Nelson 1997) the oxidation of sulfide in bacterial mats consumes 37 to $47 \mathrm{mmolO}_{2} \mathrm{~m}^{-2} \mathrm{~d}^{-1}$ which is similar to the average total sediment oxygen consumptions rate of $38 \mathrm{mmolO}_{2} \mathrm{~m}^{-2} \mathrm{~d}^{-1}$ determined using benthic chamber landers at the microbial mat sites during the same cruise (Linke et al. 1999). These calculations demonstrate that only a minor fraction of the total oxygen is consumed by processes such as aerobic methane oxidation, confirming the finding of Boetius et al. (2000) who found that methane is oxidised primarily anaerobically, linked to sulfate reduction at the methane rich sediments of the Hydrate Ridge. However, Beggiatoa is also able to denitrify efficiently, and this can be an important mechanism at low oxygen concentrations in the overlying water column. When the buffering capacity of bacterial mat sediments is exceeded, the sulfide flux is controlled by the amount of sulfide released during decomposition of SGH and the amount produced during anaerobic methane oxidation. Since sulfide release during decomposition of SGH is not known, anaerobic methane turnover, which is of crucial importance for the degradation kinetics of gas hydrates, cannot be estimated. These considerations do not apply to clam field sediments since the SSBB consists of different groups of organisms.

In order to assess the contribution of POC from primary production at the water surface to the bulk POC (defined as the sum of allochthonous and autochthonous POC input) available to benthic consumers, the vertical deposition of allochthonous POC at the SGH and control sites was estimated from water depth, the surface primary production and empirical equations (Suess 1980, Betzer et al. 1984, Berger et al. 1987, Pace et al. 1987). Primary production rates were taken for July (Antoine et al. 1996), 1 mo prior to sediment sampling. Since the depth difference between control and SGH sites is only about $50 \mathrm{~m}$, differences in POC flux are negligible (Table 3). For the SGH sites POC flux rates in the range of 27.1 to $110.3 \mathrm{mg} \mathrm{C} \mathrm{m}^{-2} \mathrm{~d}^{-1}$ were calculated. The estimated relative contribution of the autochthonous POC source in the sediment to the bulk POC was 5 to $17 \%$ at the control sites and to 35 to $87 \%$ at the SGH sites. At the clam field sites, however, additional autochthonous POC production by symbiotic bacteria in the vesicomyids was not considered in the calculations.

Due to the particular topography of the Hydrate Ridge (see Fig. 1b) the lateral input of POC is difficult to assess, but it could be substantial at this continental margin habitat (Bauer \& Druffel 1998, Antia et al. 1999). Thus the allochthonous POC inputs are underestimated, and this further reduces the relative contribution of autochthonous POC in the bulk carbon budget of the control and SGH sediments. The average supply of bulk POC at SGH sites was 3.1 times higher than at the control sites, which might be sufficient to sustain SSBB biomasses almost 4 times higher.

The more distant reference sites in the Western and Eastern Basins, located at water depths of $2304 \mathrm{~m}$ and $1285 \mathrm{~m}$, respectively, showed higher TA and higher DNA inventories than the control sites. Due to their proximity to the Hydrate Ridge and the continental slope, these basins may accumulate fresh organic material from down-slope transport of $\mathrm{POC}$, leading to increased standing stocks of the SSBB.

Inventories of chl $a$ and pheopigments were determined as a measure of POC input from phytodetritus. Although vertical POC fluxes differ only very little (Tab. 3), the chl $a$ and pheopigment inventories at the SGH sites were about half that of the control sites located only some hundreds of meters away.

The clam field sediments are densely populated by Calyptogena sp., and by Acharax sp. when the sulfide flux decreases and the sulfide front recedes into the sediment (Sahling et al. 2002). Due to the association with endosymbiotic sulfide-oxidising bacteria, filter feeding is of minor importance in Calyptogena sp. (Fiala-Médioni \& Métivier 1986, von Mirbach 2000), which possess a reduced digestive system and do not filter high quantities of organic matter. Hence, filter feeding by these clams is hardly responsible for the reduced pigment inventories at clam field sites. Most of the filtered particles will be deposited into the sediment after a certain lag phase. Thus, one would expect that inventories of pheopigments, which have a longer degradation halftime than chl a (Stephens et al. 1997), are similar to those of the control sites, which was not the case. This does not explain the lower inventories of plant pigments in bacterial mat sediments, where very little bioturbation and bioirrigation occurs. 
The degradation kinetics of organic matter under anoxic conditions is still not fully understood and the subject of controversial discussions (cf. Middelburg et al. 1993, Holmer 1999). However, we assume that enhanced microbial degradation of phytodetrital $\mathrm{C}_{\text {org }}$ may explain the reduced pigment inventories. Westrich \& Berner (1984), Henrichs \& Reeburgh (1987), Lee (1992), and Sun et al. (1993) found similar or faster decay rates of chl a under anoxic conditions compared to oxic ones. Kristensen et al. (1995) demonstrated that labile, easily hydrolisable material is degraded at the same rates under oxic and anoxic conditions, whereas complex molecules show less efficient anaerobic mineralisation. Luth et al. (1999) also measured reduced pigment inventories at methane seeps in comparison to non-seepage control sites below $130 \mathrm{~m}$ water depth in the Black Sea. Both methane seeps and controls were exposed to low oxygen contents in the overlying water body. Thus oxygen availability is of minor significance in explaining these low plant pigment inventories. Degradation of otherwise more refractory organic matter such as the degradation products of chl a (pheophytin and pheophorbides) can be enhanced in the presence of other labile organic carbon compounds (Canfield 1994). These low molecular weight compounds can be produced by, e.g., acetogenesis and microbial autotrophic processes associated with methane turnover at SGH sediments.

\section{Stimulation of autochthonous benthic turnover due to allochthonous organic carbon influx?}

FDA turnover indicates ester-cleaving bacterial exoenzymatic activity, which is a first step and the rate limiting factor in microbial heterotrophic degradation of organic matter (Meyer-Reil 1991).

Since FDA turnover was found to be a positive linear function of DNA stocks at control, clam field and bacterial mat sites, one would expect higher overall FDA turnover rates to correspond to higher overall DNA levels at SGH sites. However, FDA turnover of the sediment at the SGH sites was not distinctively different from that measured at the control sites, maybe due to the vertical distribution of FDA turnover. The vertical gradients of FDA turnover were very steep in bacterial mats, with a peak in the uppermost sediment layer (Fig. 4). This sediment horizon was also the location of highest sulfate reduction rates (Boetius et al. 2000) and highest ${ }^{14} \mathrm{CO}_{2}$ uptake (Fig. 5). The average FDA turnover rates in the top $1 \mathrm{~cm}$ layer of bacterial mat sites was 1.7 times higher than at the control sites. Clam field sediments did not show such a consistent pattern, and vertical distribution of FDA turnover was variable. Elevated ${ }^{14} \mathrm{CO}_{2}$ uptake was found in greater sediment depths, which coincided with the vertical distribution of $\mathrm{H}_{2} \mathrm{~S}$ (Bohrmann et al. 2000).

Using chl a as a covariate, instead of comparing overall turnover rates, FDA turnover rates were significantly higher $(\mathrm{p}<0.01)$ at the SGH sites than at the control sites (Fig. 8). The linear relationship between FDA turnover and chl $a$ at both sites indicates a strong interdependence with the allochthonous organic influx through the water column, even at the autotrophically dominated SGH sites. Such a correlation between FDA turnover and plant pigment concentrations has also been found under oxic conditions in Arctic sediments north of Svålbard (Soltwedel et al. 2000) and in the Celtic Sea (Pfannkuche \& Soltwedel 1998).

In $\mathrm{SGH}$ sediments, anaerobic methane oxidation is a key process by which energy of methane released from SGH is transferred into reduced sulfur species potentially entering the benthic food web via autotrophic reactions (Fig. 9). For SGH sediments at the Hydrate Ridge, Boetius et al. (2000) provided microscopic evidence for a consortium of methanogenic archaea and sulfate reducing bacteria apparently mediating anaerobic methane oxidation. However, it is unclear which metabolites are exchanged between the archaea and the sulfate reducers (DeLong 2000). Sulfate reduction rate activity and growth of sulfatereducing bacteria depends on the availability of an electron acceptor, an electron donor and a suitable carbon source. Although we do not know how the hypothesised microbial degradation of plant pigments occurs at the SGH sites, the low molecular weight end products produced by the enhanced hydrolysis of organic matter may sustain the high sulfate reduction rates measured at the SGH sites (Boetius et al. 2000). Also, sulfate reduction is stimulated by, e.g., the experimental addition of $\mathrm{C}_{\text {org }}$ to biofilms (Kühl \& Jørgensen 1992), the light-dependent release of organic substrates by cyanobacterial mats (Fründ \& Cohen 1992) or seagrass roots (Blaabjerg et al. 1998).

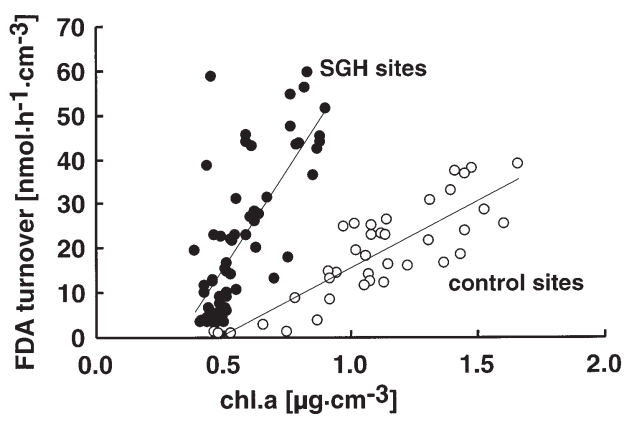

Fig. 8. Correlation between depth specific FDA turnover rates and corresponding chl a concentrations at control sites (O) and SGH sites $(\bullet)$ 


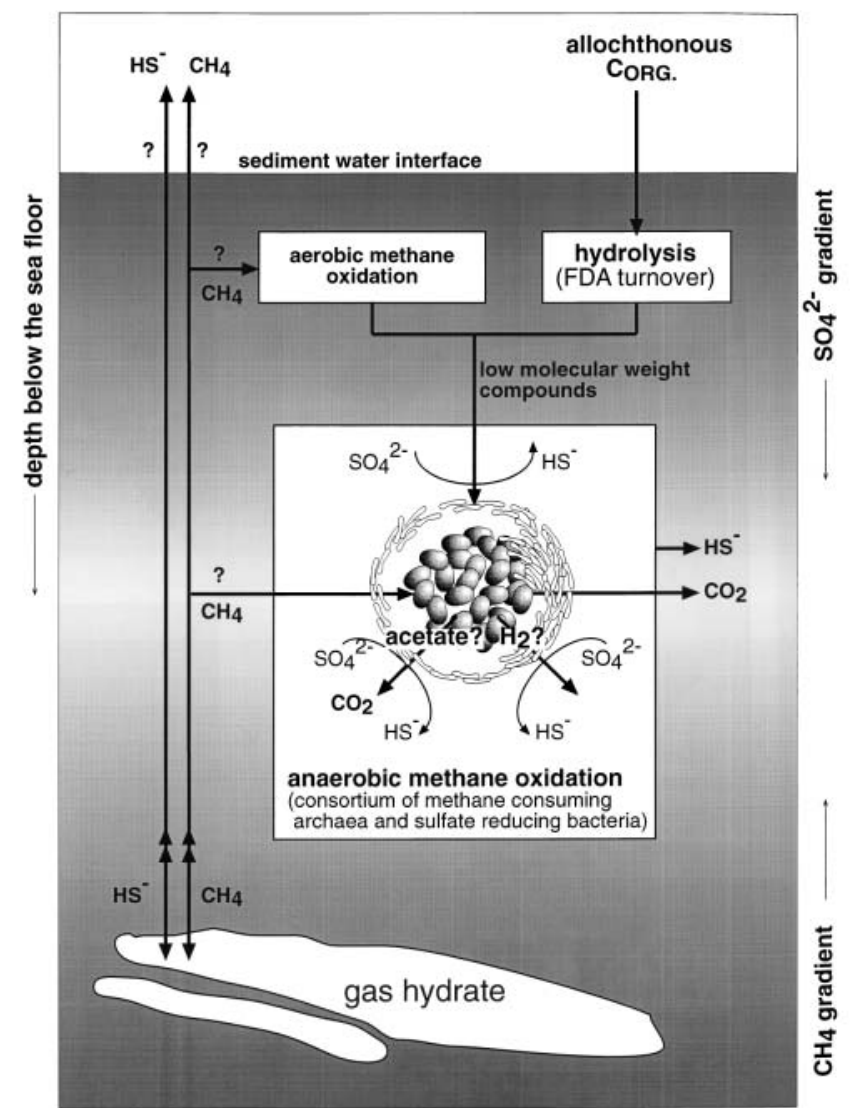

Fig. 9. Diagram of the consortium of methane-consuming archaea and sulfate-reducing bacteria. Low molecular weight organic carbon compounds released by hydrolysis of allochthonous $\mathrm{C}_{\text {org }}$ stimulate anaerobic methane oxidation in surficial gas hydrate sediments. Anaerobic methane oxidation is carried out by a consortium of sulfate-reducing bacteria (white cells) and methane consuming archaea (grey shaded cells), causing low methane and sulfate concentrations at the interface of their gradients. This syntrophic consortium may be a prominent interface between the cycling of gas hydratederived carbon with the cycling of allochthonous $\mathrm{C}_{\text {org }}$. Modified after DeLong (2000)

Olu et al. (1997) speculate that stable gas hydrates brought into contact with seawater will dissociate until the methane concentration in the pore water is in equilibrium with the hydrate. Due to the low solubility of methane within the hydrate stability field, leaching of methane from the gas hydrate will only occur if methane is continuously removed. In addition to diffusive transport, this removal of methane will be 'catalysed' by bacterial methane oxidation, probably creating and maintaining steep methane concentration gradients in SGH. Thus, variable supply of allochthonous $\mathrm{C}_{\text {org }}$ to $\mathrm{SGH}$ sites, which is directly linked to the anaerobic methane turnover via sulfate reduction, may affect the degradation kinetics of gas hydrates and the efficiency of the 'benthic filter' controlling the flux of methane across the sediment water interface. Under these considerations, sulfate reduction at SGH sites is a prominent interface for the cycling of allochthonous $\mathrm{C}_{\text {org }}$ and methane-derived carbon from decomposing $\mathrm{SGH}$. At methane seep sites in greater water depths the effect of allochthonous organic matter input on the autochthonous carbon cyling may be less important.

A second process may enhance benthic turnover in clam field sediments, explaining the 3.2-fold ${ }^{14} \mathrm{CO}_{2}$ in comparison to bacterial mat sediments. Olu et al. (1997) described that gas hydrates induce density driven convectional fluid flow in clam field sediments at mud volcanoes seaward of the Barbados accretionary prism. This redistributes solutes and microparticulates within the sediment column and enhances fluxes across the sediment-water interface. Dando et al. (1994), O'Hara et al. (1995) and Zimmermann et al. (1997) recognised convectional porewater fluid flow as responsible for the displacement of biogeochemical reaction zones, i.e. sediment horizons dominated by processes such as methane oxidation, and transition zones such as the sulphidic-oxic interface. Wallmann et al. (1997) found that bioirrigation can be a dominant transport process and strongly affect chemical gradients within the top tens of centimeters of sediments beneath clam colonies at vent sites of the eastern Aleutian subduction zone. At clam field sites, overlying seawater could be drawn into the sediment by the pumping activity of the clams, thus replenishing sulfate, oxygen, POC, and dissolved organic matter in deeper sediment horizons, and stimulating sulfate reduction.

Acknowledgements. We are grateful for the support of the officers and crew of RV 'Sonne' during cruise SO 143/2. Many thanks are due to F. Gutthann, W. Queisser, B. Scheffler and $\mathrm{T}$. Treude for their assistance aboard the ship and in the laboratory. We thank M. Drews, R. Schmaljohann and U. Rabsch for support with the ${ }^{14} \mathrm{CO}_{2}$ uptake method. We are also grateful to C. Utecht for assistance with the manuscript and figures. Cruise SO 143/2 was supported by the German Federal Ministry of Research and Education (BMBF) as part of the TECFLUX project, contract no. Fkz03G0143A.

\section{LITERATURE CITED}

Antia AN, von Bodungen B, Peinert R (1999) Particle flux across the mid European continental margin. Deep-Sea Res 46:1999-2024

Antoine D, Andre JM, Morel A (1996) Oceanic primary production. 2. Estimation at global scale from satellite (coastal zone color scanner) chlorophyll. Global Biogeochem Cycles 10:57-69

Baggarinao T (1992) Sulfide as an environmental factor and toxicant: tolerance and adaptations in aquatic organisms. Aquat Toxicol 24:21-62

Barnett PRO, Watson J, Conelly D (1984) A multiple corer for 
taking virtually undisturbed samples from the shelf, bathyal and abyssal sediments. Oceanol Acta 7:399-108

Bauer JE, Druffel, ERM (1998) Ocean margins as significant source of organic matter to the deep open ocean. Nature 392:482-485

Berger WH, Fischer K, Lai C, Wu G (1987) Ocean carbon flux: global maps of primary production and export production. In: Agegian C (ed) Biogeochemical cycling and fluxes between the deep euphotic zone and other oceanic realms. NOAA Undersea Res Prog 3:1-44

Betzer PR, Showers WJ, Laws EA, Winn CD, DiTullio GR, Kroopnick PM (1984) Primary productivity and particle fluxes on a transect of the equator at $153^{\circ} \mathrm{W}$ in the Pacific Ocean. Deep-Sea Res Part I Oceanogr Res Pap 31:1-11

Blaabjerg V, Mouritsen KN, Finster K (1998) Diel cycles of sulphate reduction rates in sediments of a Zostera marina bed (Denmark). Mar Ecol Prog Ser 15:97-102

Boetius A, Ravenschlag $\mathrm{K}$, Schubert CJ, Rickert D and 6 others (2000) A marine microbial consortium apparently mediating anaerobic oxidation of methane. Nature 407: $623-626$

Bohrmann G, Greinert J, Suess E, Torres M (1998) Authigenic carbonates from Cascadia subduction zone and their relation to gas hydrate stability. Geology 26:647-650

Bohrmann G, Linke P, Suess E, Pfannkuche O (2000) FS Sonne Cruise Report SO143. GEOMAR Report 93, Kiel

Canfield DC (1994) Factors influencing organic carbon preservation in marine sediments. Chem Geol 114:315-329

Carson B, Westbrook GK (1995) Modern fluid flow in the Cascadia accretionary wedge: a synthesis. In: Carson B, Westbrook GK, Musgrave RJ, Suess E (eds) Proc ODP Sci Results. College Station, TX, p 413-421

Dando PR, Austen MC, Burke Jr RA, Kendall MA and 6 others (1991) Ecology of a North Sea pockmark with an active methane seep. Mar Ecol Prog Ser 107:157-167

Dando PR, Jensen P, O'Hara SCM, Niven SJ, Schmaljohann P, Schuster U, Taylor LJ (1994) The effects of methane seepage at an intertidal/shallow subtidal site on the shore of the Kattegat, Vensyssel, Denmark. Bull Geol Soc Den 41:65-79

DeLong EF (2000) Resolving a methane mystery. Nature 407:577-579

Desbruyères D, Toulmond A (1998) A new species of hesionid worm, Hesiocaeca methanicola sp. nov. (Polychaeta: Hesionidae), living in ice-like methane hydrates in the deep Gulf of Mexico. Cah Biol Mar 39:93-98

Ferdelman TG, Lee C, Pantoja S, Harder J, Bebout BM, Fossing H (1997) Sulfate reduction and methanogenesis in a Thioploca-dominated sediment off the coast of Chile. Geochim Cosmochim Acta 61:3065-3079

Fiala-Médioni A, Métivier C (1986) Ultrastructure of the gill of the hydrothermal vent bivalve Calyptogena magnifica, with a discussion of its nutrition. Mar Biol 90:215-222

Fründ C, Cohen Y (1992) Diurnal cycles of sulfate reduction under oxic conditions in cyanobacterial mats. Appl Environ Microbiol 58:70-77

Gallardo VA (1977) Large benthic microbial communities in sulphide biota under Peru-Chile subsurface countercurrent. Nature 286:331-332

Gutzmann E (2002) Meiobenthosgesellschaften in gashydrathaltigen marinen Sedimenten des Hydratrückens, Cascadia Subduktionszone. MS thesis, University of Kiel

Hagen KD, Nelson DC (1997) Use of reduced sulfur compounds by Beggiatoa spp.: enzymology and physiology of marine and freshwater strains in homogeneous and gradient cultures. Appl Environ Microbiol 63:3957-3964

Henrichs SM, Reeburgh WS (1987) Anaerobic mineralization of marine sediment organic matter: rates and role of anaerobic processes in the oceanic carbon economy. Geomicrobiol J 5:191-237

Hoehler TM, Alperin MJ, Albert DB, Martens CS (1994) Field and laboratory studies of methane oxidation in an anoxic marine sediment: evidence for a methanogen-sulfate reducer consortium. Global Biogeochem Cycles 8: 451-463

Hollinde M (1995) Untersuchungen in Sedimenten des Nordsylter Wattenmeeres: mikrobielle Produktion und Austauschraten an der Sediment/Wasser-Grenzfläche. PhD thesis, University of Kiel

Holmer M (1999) The effect of oxygen depletion on anaerobic organic matter degradation in marine sediments. Estuar Coast Shelf Sci 48:383-390

Holm-Hansen O, Lorenzen CJ, Holmes RW, Strickland JDH (1965) Fluorometric determination of chlorophyll. J Cons Perm Int Explor Mer 30:3-15

Jensen P (1986) Nematode fauna in the sulphide-rich brine seep and adjacent bottoms of the East Flower Garden, NW Gulf of Mexico. Mar Biol 92:489-503

Jensen P, Aaagaard I, Burke RA Jr, Dando PR and 5 others (1992) 'Bubbling reefs' in the Kattegat: submarine landscapes of carbonate-cemented rocks support a diverse ecosystem at methane seeps. Mar Ecol Prog Ser 83:103-112

Jørgensen BB (1987) Ecology of the sulphur cycle: oxidative pathways in sediments. In: Cole JA, Ferguson SJ (eds) The nitrogen and sulphur cycles. 42nd Symp Soc Gen Microbiol, University of Southampton. Cambridge University Press, Cambridge

Kapuscinski J, Skoczylast B (1977) Simple and rapid fluorimetric method for DNA microassay. Anal Biochem 83: 252-257

Karl DM (1993) Total microbial biomass estimation derived from the measurement of particulate adenosine-5' triphosphate. In: Kemp PF, Sherr BF, Sherr EB, Cole JJ (eds) Handbook of methods in aquatic microbial ecology, Lewis, Boca Raton, FL, p 359-368

Kastner M, Sample JC, Whiticar MJ, Hovland M, Cragg BA, Parkes JR (1995) Geochemical evidence for fluid flow and diagenesis at the Cascadia convergent margin. In: Carson B, Westbrook GK, Musgrave RJ, Suess E (eds) Proc ODP Sci Results. College Station, TX, p 375-384

Kastner M, Kvenvolden KA, Lorenson T (1998) Chemistry, isotopic composition, and origin of methane hydrogen sulfide hydrate at the Cascadia subduction zone. Earth Planet Sci Lett 156:173-183

Kristensen E, Ahmed SI, Devol AH (1995) Aerobic and anaerobic decomposition of organic matter in marine sediments: which is fastest. Limnol Oceanogr 40:1430-1437

Kühl M, Jørgensen BB (1992) Microsensor measurements of sulfate reduction and sulfide oxidation in compact microbial communites of aerobic biofilms. Appl Environ Microbiol 58:1164-1174

Kulm LD, Suess E, Moore JC, Carson B and 10 others (1986) Oregon subduction zone: venting, fauna, and carbonates. Science 231:561-566

Kvenvolden KA, (1988a) Methane hydrates and global climate. Global Biogeochem Cycl 2:221-229

Kvenvolden KA (1988b) Methane hydrate-a major reservoir of carbon in the shallow geosphere? Chem Geol 71:41-51

Kvenvolden KA (1993) Gas hydrates - geological perspective and global change. Rev Geophys 31:173-183

Lee C (1992) Controls on organic carbon preservation: the use of stratified water bodies to compare intrinisic rates of decomposition in oxic and anoxic systems. Geochim Cosmochim Acta 56:3323-3325 
Levin LA, James DW, Martin CM, Rathburn AE, Harris LH, Michener RH (2000) Do methane seeps support distinct macrofaunal assemblages? Observations on community structure and nutrition from the northern California slope and shelf. Mar Ecol Prog Ser 208:21-39

Linke P, Pfannkuche O, Torres ME, Collier R and 6 others (1999) Variability of benthic flux and discharge rates at vent sites determined by in situ instruments. EOS Trans Am Geophys Union 80(46):SupplF509

Luth C, Luth U, Gebruk, AV, Thiel H (1999) Methane gas seeps along the oxic/anoxic gradient in the Black Sea: manifestations, biogenic sediment compounds and preliminary results on benthic ecology. PSZN I: Mar Ecol 20: 221-249

MacDonald I, Joye S (1997) Lair of the 'ice worm'. Quarterdeck 5:5-7

MacKay ME, Moore GF, Cochrane GR, Moore JC, Kulm LD (1992) Landward vergence and oblique structural trends in the Oregon margin accretionary prism: implications and effect on fluid flow. Earth Planet Sci Lett 109:477-491

Masuzawa TH, Kitagawa H, Kusakabe M (1992) Sulfate reduction using methane in sediments beneath a bathyal cold seep giant clam community off Hatsushima Island, Sagami Bay Japan. Earth Planet Sci Lett 110:39-50

Meyer-Reil LA (1991) Ecological aspects of enzymatic activities in marine sediments. In: Chrost RJ (ed) Microbial enzymes in aquatic environments. Springer Verlag, New York, p 84-95

Meyer-Reil LA, Köster M (1992) Microbial life in pelagic sediments: the impact of environmental parameters on enzymatic degradation of organic material. Mar Ecol Prog Ser 81:65-72

Middelburg JJ, Vlug T, van der Nat F, Jaco WA (1993) Organic matter mineralization in marine systems. Global Planet Change 8:47-58

O'Hara SCM, Dando PR, Schuster U, Bennis A and 5 others (1995) Gas seep induced interstitial water circulation: observations and environmental implications. Cont Shelf Res 15:931-948

Olu K, Lance S, Sibuet M, Henry P, Fiala-Médioni A, Dinet A (1997) Cold seep communities as indicators of fluid expulsion patterns through mud volcanoes seaward of the Barbados accretionary prism. Deep-Sea Res 44:811-841

Pace ML, Knauer GA, Karl DM, Martin JH (1987) Primary production, new production and vertical flux in the Eastern Pacific. Nature 325:803-804

Pfannkuche O, Soltwedel T (1998) Small benthic size classes along the N.W. European continental margin: spatial and temporal variability in activity and biomass. Prog Oceanogr 42:189-207

Pfannkuche O, Boetius A, Lochte $\mathrm{K}$, Lundgreen U, Thiel H (1999) Responses of deep-sea benthos to sedimentation patterns in the North-East Atlantic. Deep-Sea Res 46: 573-596

Pfannkuche O, Sommer S, Kähler A (2000) Coupling between phytodetritus deposition and the small-sized benthic biota in the deep Arabian Sea: analyses of biogenic sediment compounds. Deep-Sea Res Part B 47:2805-2833

Sahling H, Rickert D, Linke P, Suess E, Lee RW (2002) Community structure at gas hydrate deposits at the Cascadia convergent margin, NE Pacific. Mar Ecol Prog Ser 231: 121-138

Schmaljohann R (1996) Methane dynamics in the sediment and water column of Kiel Harbour (Baltic Sea). Mar Ecol Prog Ser 131:263-273

Editorial responsibility: Otto Kinne (Editor), Oldendorf/Luhe, Germany
Schmaljohann R, Drews M, Walter S, Linke P, von Rad U, Imhoff JF (2001) Oxygen-minimum zone sediments in the northeastern Arabian Sea off Pakistan: a habitat for the bacterium Thioploca. Mar Ecol Prog Ser 211:27-42

Schulz HN, Jørgensen BB, Fossing H, Ramsing NB (1996) Community structure of filamentous, sheath-building sulfur bacteria, Thioploca spp., off the coast of Chile. Appl Environ Microbiol 62:1855-1862

Shirayama Y, Ohta S (1990) Meiofauna in a cold-seep community off Hatsushima, Central Japan. J Oceanogr Soc Jpn 46:118-124

Sloan ED (1990) Clathrate hydrates of natural gases. Marcel Dekker, New York

Soltwedel T, Mokievsky V, Schewe I (2000) Benthic activity and biomass on the Yermak Plateau and in adjacent deep-sea regions northwest of Svålbard. Deep-Sea Res 47:1761-1785

Stephens MP, Kadko DC, Smith CR, Latasa M (1997) Chlorophyll-a and pheopigments as tracers of labile organic carbon at the central equatorial Pacific seafloor. Geochim Cosmochim Acta 61:4605-4619

Suess E (1980) Particulate organic carbon flux in the oceanssurface productivity and oxygen utilization. Nature 288: $260-263$

Suess E, Carson B, Ritger SD, Moore JC, Jones ML, Kulm LD, Cochrane GR (1985) Biological communities at vent sites along the subduction zone off Oregon. Biol Soc Wash Bull 6:475-484

Suess E, Torres ME, Bohrmann G, Collier RW and 7 others (1999) Gas hydrate destabilization: enhanced dewatering, benthic material turnover and large methane plumes at the Cascadia convergent margin. Earth Planet Sci Lett 170:1-15

Sun MY, Lee C, Aller RC (1993) Laboratory studies of oxic and anoxic degradation of chlorophyll-a in Long Island Sound sediments. Geochim Cosmochim Acta 57:147-157

Teucher MW (1986) Abschätzung der benthischen Biomasse über die Analyse von DNA. MS thesis, University of Kiel

Tryon MD, Brown KM, Torres ME, Trehu AM, McManus J, Collier RW (1999) Measurements of transience and downward fluid flow near episodic methane gas vents, Hydrate Ridge, Cascadia. Geology 2:1075-1078

Vismann B (1991) Sulfide tolerance: physiological mechanisms and ecological implications. Ophelia 34:1-27

von Mirbach N (2000) Sulfidaufnahme von Calyptogena pacifica im Vergleich mit geochemischen Untersuchungen in Cold Seep Sedimenten vor Makran und West-Java. PhD thesis, University of Kiel

Wallmann $K$, Linke P, Suess E, Bohrmann G and 6 others (1997) Quantifying fluid flow, solute mixing, and biogeochemical turnover at cold vents of the eastern Aleutian subduction zone. Geochim Cosmochim Acta 61: 5209-5219

Westrich JT, Berner RA (1984) The role of sedimentary organic matter in bacteria sulfate reduction: the $\mathrm{G}$ model tested. Limnol Oceanogr 29:236-249

Yentsch CS, Menzel DW (1963) A method for the determination of phytoplankton chlorophyll and phaeophytin by fluorescence. Deep-Sea Res 10:221-231

Zimmermann S (1999) The nematode fauna associated with methane seeps in the central Skagerrak. PhD thesis, University of London

Zimmermann S, Hughes RG, Flügel HJ (1997) The effect of methane seepage on the spatial distribution of oxygen and dissolved sulphide within a muddy sediment. Mar Geol 137:149-157

Submitted: May 28, 2001; Accepted: July 4, 2002

Proofs received from author(s): October 11, 2002 